\title{
1 Superior performance of modified pitch-based adsorbents for cyclic 2 methane storage
}

3 Shohreh Mirzaei ${ }^{1}$, Ali Ahmadpour ${ }^{1, *}$, Akbar Shahsavand ${ }^{1}$, Hamed Rashidi $^{2}$, Arash Arami-Niya ${ }^{3}$ **

${ }^{1}$ Department of Chemical Engineering, Faculty of Engineering, Ferdowsi University of Mashhad, P.O. Box 91779-48944, Mashhad, Iran.

${ }^{2}$ Department of Chemical Engineering, Shahrood Branch, Islamic Azad University, P.O. Box 36155-163, Shahrood, Iran.

${ }^{3}$ Fluid Science \& Resources Division, Department of Chemical Engineering, The University of Western Australia, Crawley, WA 6009, Australia.

Abstract

As an alternative approach for natural gas storage at relatively low pressure and ambient temperature, Adsorbed Natural Gas (ANG) has aroused tremendous interest in recent years. However, still, there is a great challenge to find a suitable adsorbent with a high capacity for gas storage. Here in this study, we reported how to prepare an activated carbon with high methane $\left(\mathrm{CH}_{4}\right)$ uptake using a low cost and abundant precursor such as coal tar pitch (CTP). The effect of two-stage treatment (acidification and carbonization) of CTP on its surface and structural properties, as well as methane adsorption capacity of the final activated carbon products, were explored. Experimental results revealed that the carbon yield of the precursor, porous textural properties, and $\mathrm{CH}_{4}$ adsorption capacity of the adsorbent were efficiently improved via optimization of the pre-treatment conditions. The AC600CTP adsorbent, as an optimum sample, shows the largest capacity of $\mathrm{CH}_{4}$ adsorption on a volumetric basis $\left(184 \mathrm{~V}_{(\mathrm{STP})} / \mathrm{V}\right)$ at $25^{\circ} \mathrm{C}$ and 40 bar. Based on the authors' knowledge, the volumetric $\mathrm{CH}_{4}$ capacity of AC600CTP is comparable with the high values reported in the literature among some different classes of the adsorbent. Finally, multiple cyclic operations on AC600CTP at $25^{\circ} \mathrm{C}$ and pressure of 40 bar showed the excellent performance of the adsorbent over the dynamic cycle test.

Keywords: Adsorbed natural gas, coal-tar pitch, adsorbent, methane storage, carbonization. 


\section{Introduction}

As a favorable fuel, natural gas produces a greater value of energy content per mass with minimal environmental impacts in comparison with the other hydrocarbons. However, the high vapor pressure of $\mathrm{CH}_{4}$ as the main component of $\mathrm{NG}$ makes its storage energy-intensive and costly; the main current methods of NG liquefaction and compression are associated with the disadvantages of expensive investment costs and difficult operating conditions. Adsorbed natural gas (ANG) system has been implemented as an alternative approach for natural gas storage, at relatively low pressure (35-40 bar) and the ambient temperature [1]. To be economically equivalent to the other NG storage techniques, the U.S. Department of Energy (DOE) has initiated the $\mathrm{CH}_{4}$ storage targets, in 1993 the DOE defined the storage target at $150 \mathrm{~cm}^{3} / \mathrm{cm}^{3}$ for a final pressure of $3.5 \mathrm{MPa}$. A few years later, this target was raised up to $180 \mathrm{~cm}^{3} / \mathrm{cm}^{3}$ at the same pressure conditions. Since 2012, the DOE target has been set 263 $\mathrm{cm}^{3} / \mathrm{cm}^{3}$ (for volumetric measurements) and $0.5 \mathrm{~kg} / \mathrm{kg}$ (for gravimetric capacity)[2, 3].

The amount of $\mathrm{CH}_{4}$ adsorption extremely depends on the interaction between the gas and adsorbent. Therefore, to fully utilize the adsorbed natural gas systems, it is very necessary to find adequate porous materials with a high capacity of gas adsorption under a relatively low storage pressure of 35- 40 bar. So far, many valuable attempts have been made to synthesis efficient adsorbents such as activated carbons (ACs), high surface area activated carbons (HSACs), metal-organic frameworks (MOFs) and active carbon fibers (ACFs) [4-9]. Among all types of adsorbents, activated carbons (ACs) have received considerable attention due to their low production cost, availability and relatively high $\mathrm{CH}_{4}$ adsorption capacity $[7,10]$.

In the preparation of activated carbon with favorable pore structure, it is essential to find a proper precursor and preparation method. So far, many kinds of carbonaceous precursors such as coal, petroleum coke, pitches, polymers, and biomass have been suggested to prepare activated carbon for the ANG purposes [11-13]. Among all types of precursors, coal tar pitch (CTP) based adsorbents with high carbon content, foam-like hierarchical pore structures, and connected macropores have been shown proper thermal and electrical conduction properties and good capability in $\mathrm{CH}_{4}$ storage[5, 14]. Furthermore, coal tar pitch is truly cheap and commonly available in the petrochemical industry. 
Modification of the CTP precursor's structure before the activation procedure can be an effective preparation method to obtain the CTP-based adsorbents with a high capacity of $\mathrm{CH}_{4}$ adsorption $[6,15]$. Although numerous researches focused on the effect of activation conditions on gas adsorption properties of activated CTPs [5, 6], only a few reports deal with the impact of pre-treatment step of pitch-based adsorbents [16]. The matrix structure of the CTP material is associated with sorts of volatile components that come out of the structure or will be converted to carbon by treatment of the sample. The removal of these volatile matters results in higher viscosity and density of the melted CTP at higher temperatures [17]. Two-stage pre-treatment of the CTP materials, including acidification and carbonization, can be applied before chemical activation of the samples [6, 7]. During acid treatment, volatile compounds will be removed gently, while in thermal step (carbonization process), organic substances converted into carbon or a carbon-containing residue [6]. In this article, the preparation condition of CTP-based adsorbents has been optimized to reach the maximum capacity of $\mathrm{CH}_{4}$ storage for the ANG applications. Herein, the CTPs samples were modified via acidification and carbonization processes. The effect of the modification step on the porous texture properties and $\mathrm{CH}_{4}$ storage capacity of the activated CTPs was evaluated. The equilibrium isotherm of $\mathrm{CH}_{4}$ adsorption was measured at three different temperatures; these empirical data were modeled with the Toth equation. Isosteric heat of adsorption was extracted from the Van't Hoff equation. Finally, the global storage performance of the best sample was assessed inside the ANG vessel as a function of the cycle number. To the best of our knowledge, this comprehensive approach has not been addressed in previous researches and makes a significant improvement in $\mathrm{CH}_{4}$ storage capacity for ANG purposes.

\section{Experimental}

\subsection{Materials}

A coal tar pitch (CTP) as a precursor, with softening point of $220^{\circ} \mathrm{C}$ was supplied by the Iranian Research Institute of Petroleum Industry. Potassium hydroxide and nitric acid with high quality were purchased from Merck KGA Company, Germany. $\mathrm{CH}_{4}$ with the purity of $99.99 \%$ was obtained from 
employed with ultra-high purity of 99.999\% provided from Sepehr Gas Company, Iran. Nitrogen with stated purity of $99.9 \%$, bought from Malaekeh company, Iran.

\subsection{Two-stage treatment of coal-tar pitch (acidification and carbonization)}

To modify the structure of the CTP samples, first, $10 \mathrm{~g}$ of CTP was placed in a round bottom flask $(500 \mathrm{ml})$. The flask was placed in a preheated silicon bath at $270^{\circ} \mathrm{C}$ (above the CTP softening point), for $20-30 \mathrm{~min}$ to melt the sample. Then, $10 \mathrm{ml}$ of nitric acid $5 \mathrm{~mol} / \mathrm{L}$ was carefully injected dropwise to the melted pitch and the mixture was stirred with magnetic stirring at $100 \mathrm{rpm}$ for about $8-10 \mathrm{~min}$. After that, the oil bath temperature was increased gradually to the final value of $300^{\circ} \mathrm{C}$ with a heating rate of $5^{\circ} \mathrm{C} / \mathrm{min}$. Increasing the temperature leads to elevating the pitch's viscosity to the point that the solution could not be stirred anymore. At this stage, the treated sample was cooled down to room temperature.

The samples were loaded into a stainless-steel boat and carbonized in a horizontal tubular furnace under a nitrogen flow of $650 \mathrm{~mL} / \mathrm{min}$. In the carbonization process, samples were heated up to different final temperatures of $400,500,600$ and $700^{\circ} \mathrm{C}$ with a heating rate of $10^{\circ} \mathrm{C} / \mathrm{min}$ for $2 \mathrm{~h}$. The carbonized CTP samples were named based on their carbonization temperature; for example, the CTP sample carbonized at $500^{\circ} \mathrm{C}$ is called $500 \mathrm{CTP}$.

\subsection{Activation of the treated CTP samples}

Here, the chemical activation was carried out according to the optimized activation conditions from our previous reports [18-22], (where the maximum $\mathrm{CH}_{4}$ storage capacity was achieved). The carbonized samples had a solid and brittle shape at room temperature. The CTP solid was ground and sieved to a particle size less than $200 \mu \mathrm{m}$, and then physically well-mixed with powder of $\mathrm{KOH}$ as a chemical agent $[12,23]$. In the activation process of CTPs, the preparation parameters including $\mathrm{CTP} / \mathrm{KOH}$ ratio, activation temperature and activation time were $1: 4,800^{\circ} \mathrm{C}$ and $3 \mathrm{~h}$, respectively. The produced ACs were thoroughly washed with distilled water to reach the neutral $\mathrm{pH}(\sim 6)$, afterward, the adsorbents dried at $130^{\circ} \mathrm{C}$ in the oven for $24 \mathrm{~h}$. The prepared ACs were denoted based on their carbonization 

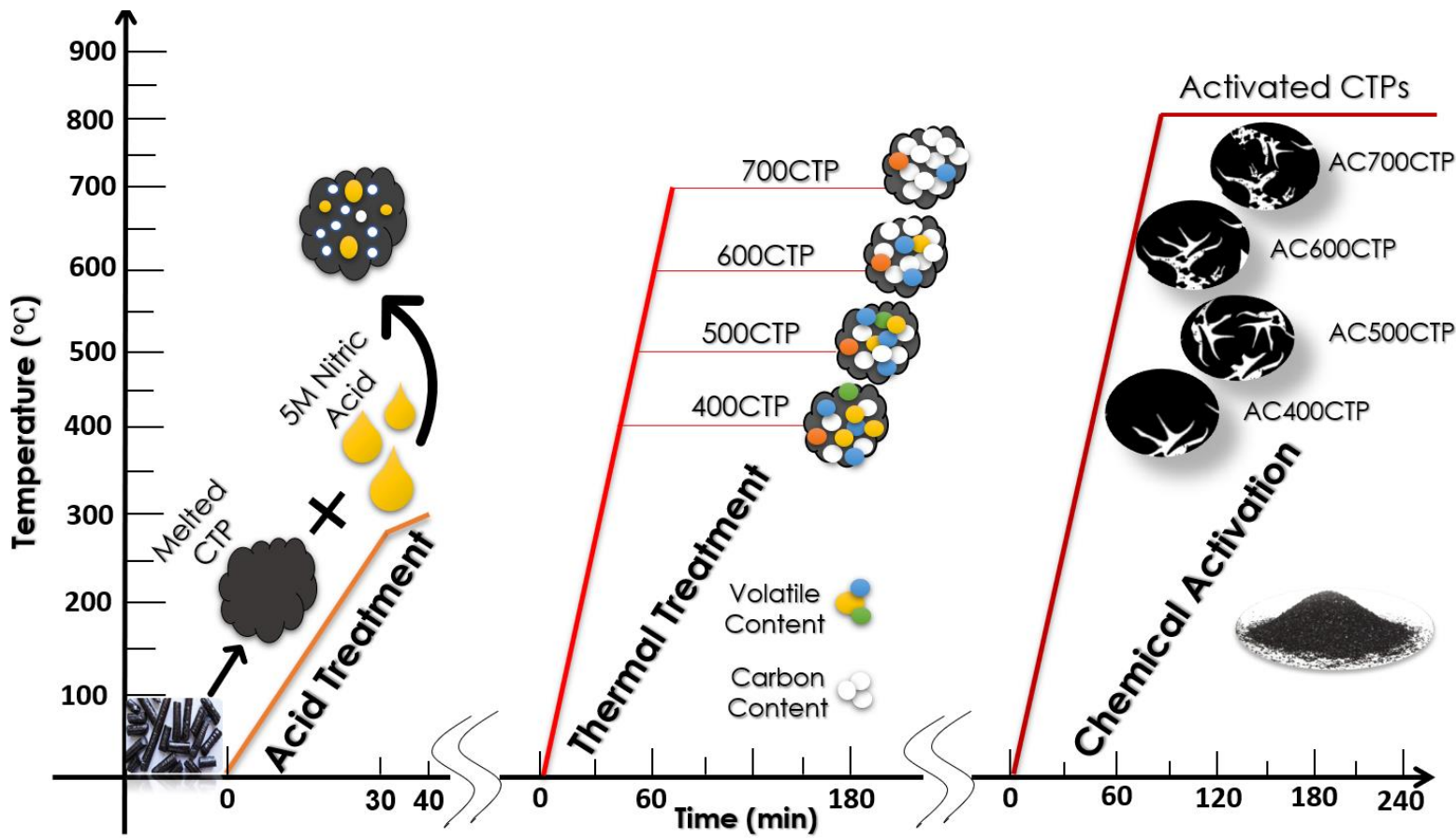

Figure 1. A schematic illustration for preparation pathway of CTP-based adsorbent.

\subsection{Characterization of pitch-based AC samples}

111 Elemental analysis of the CTP-based samples was performed by the Thermo Finnigan EA 1112 analyzer (Thermo Fisher, USA). The packing density of the ACs was measured according to the standard test method of D2854, in a small stainless-steel cylinder with a $1 \mathrm{~cm}$ diameter and about $15 \mathrm{~cm}$ height [24]. For each measurement, $2 \mathrm{~g}$ of the sample was placed into a graduated cylinder and pressurized up to $500 \mathrm{~kg} / \mathrm{cm}^{2}$, [25]. Packing density is calculated by dividing the measured weight per volume of each sample. The measurements were repeated three times and densities had an error of less than $3 \%$.

The pore structure of the $\mathrm{AC}$ samples was characterized by $\mathrm{N}_{2}$ adsorption/desorption measurements at $-196^{\circ} \mathrm{C}$ using an automatic adsorption system of Belsorp Mini II (BEL, Japan). The Brunauer Emmett Teller (BET) method was used to determine the surface area of the samples in the relative pressure range of $0.05 \leq \mathrm{P} / \mathrm{P}_{0} \leq 0.3$. The total pore volume of the samples $\left(\mathrm{V}_{\text {tot }}\right)$ was calculated at $\mathrm{P} / \mathrm{P}_{0}=0.99$ and micropore volumes $\left(\mathrm{V}_{\text {mic }}\right.$ ) up to $\mathrm{P} / \mathrm{P}_{0} \sim 0.1$ (for pores $<2 \mathrm{~nm}$ ) were established based on the non-local 
density functional theory (DFT) model. The difference between $\mathrm{V}_{\text {tot }}$ and $\mathrm{V}_{\text {mic }}$ is the mesopore volume

$124\left(\mathrm{~V}_{\text {meso }}\right)$. The presence of functional groups on all the samples were specified through Fourier Transform Infrared Spectroscopy (FTIR) measurement by KBr pellet method using and a Thermo Nicolet Avatar370 spectrometer (Nexus, USA). The infrared region in FTIR spectroscopy was selected in the range of $500 \mathrm{~cm}^{-1}$ to $4000 \mathrm{~cm}^{-1}$ wave number. To identify the crystalline phases, XRD patterns were analyzed by Explorer X-Ray equipment (GNR, Italy), with a detector type of scintillator in the range of $10<2 \theta<60$.

\subsection{Methane adsorption measurements}

\subsubsection{High-pressure volumetric system}

131 A custom volumetric adsorption apparatus was employed for the analysis of equilibrium $\mathrm{CH}_{4}$ adsorption at a constant temperature of $25^{\circ} \mathrm{C}$ and pressure up to 40 bar. Figure 2 shows the schematic arrangement of the adsorption measurement apparatus. Here, we provide a brief description of the critical features of the apparatus, and the experimental workflow used to measure $\mathrm{CH}_{4}$ adsorption.

The volume of the dosing cell $\left(V_{D}\right)$ and the adsorption cell $\left(V_{A}\right)$ were determined using helium as an inert gas with the assumption of negligible helium adsorption. The volume calibration was repeated three times $\left(V_{A}=9.75 \pm 0.05 \mathrm{~cm}^{3}\right.$ and $\left.V_{D}=125 \pm 0.05 \mathrm{~cm}^{3}\right)$. The dosing cell and adsorption cell temperature were kept at $25{ }^{\circ} \mathrm{C}$ using a circulating water bath. The temperature of the water bath and two cells were monitored by PT100 sensors with an uncertainty of $1 \mathrm{~m}^{\circ} \mathrm{C}$. The pressure in the adsorption cell was measured using Honeywell pressure transducers with a full scale of 50 bar, and the accuracy of $\pm 0.1 \%$ full scale.

Before each experiment, $1 \mathrm{~g}$ of the AC sample was dried at $100{ }^{\circ} \mathrm{C}$ in a vacuum oven overnight. Afterward, the sample immediately transferred to the adsorption cell. Both dosing and adsorption cells were evacuated to $10^{-4}$ bar by a vacuum pump (platinum JB, USA) for $5 \mathrm{~h}$ and the temperature of adsorption cell was kept in the range of $150-200{ }^{\circ} \mathrm{C}$ by a heating element for degassing during the mentioned time. Subsequently, the dosser cell and adsorption cell were kept at $25^{\circ} \mathrm{C}$ using a circulating water bath. The entire system was isolated from the surroundings to avoid temperature changes. When the temperature was stable, The sample's true volume has been determined by helium calibration, 

assuming negligible helium adsorption on the AC samples at pressures below 10 bar [26]. After the evacuation of the cell, $\mathrm{CH}_{4}$ was injected into the dosing cell by opening $\mathrm{V}_{2}$ and $\mathrm{V}_{3}$ up to the desired pressure $\left(\mathrm{P}_{1}\right)$. Once the pressure became steady, $\mathrm{P}_{1}$ was recorded, and the gas was loaded into the adsorption cell via the intersectional valve of $\mathrm{V}_{4}$. The adsorption cell was allowed to reach pressure stability and remain constant for more than 15 min, then $\mathrm{P}_{2}$ was recorded as the equilibrium pressure [27]. It should be noted that the whole $\mathrm{CH}_{4}$ adsorption test was performed twice to ensure the accuracy of the experiment.

The amount of adsorbed $\mathrm{CH}_{4}$ is calculated from the P-V-T data using a real gas equation of state [28]. In this article, all $\mathrm{CH}_{4}$ adsorption calculation was done based on the modified Benedict-Webb-Rubin (MBWR) equation of state (EOS). Literature data showed, in the case of $\mathrm{CH}_{4}$ adsorption, MBWR equation can work over a wide range of temperature and pressure, effectively [29]. The volumetric $\mathrm{CH}_{4}$ uptake was estimated based on the measured packing density of all the prepared samples.

161

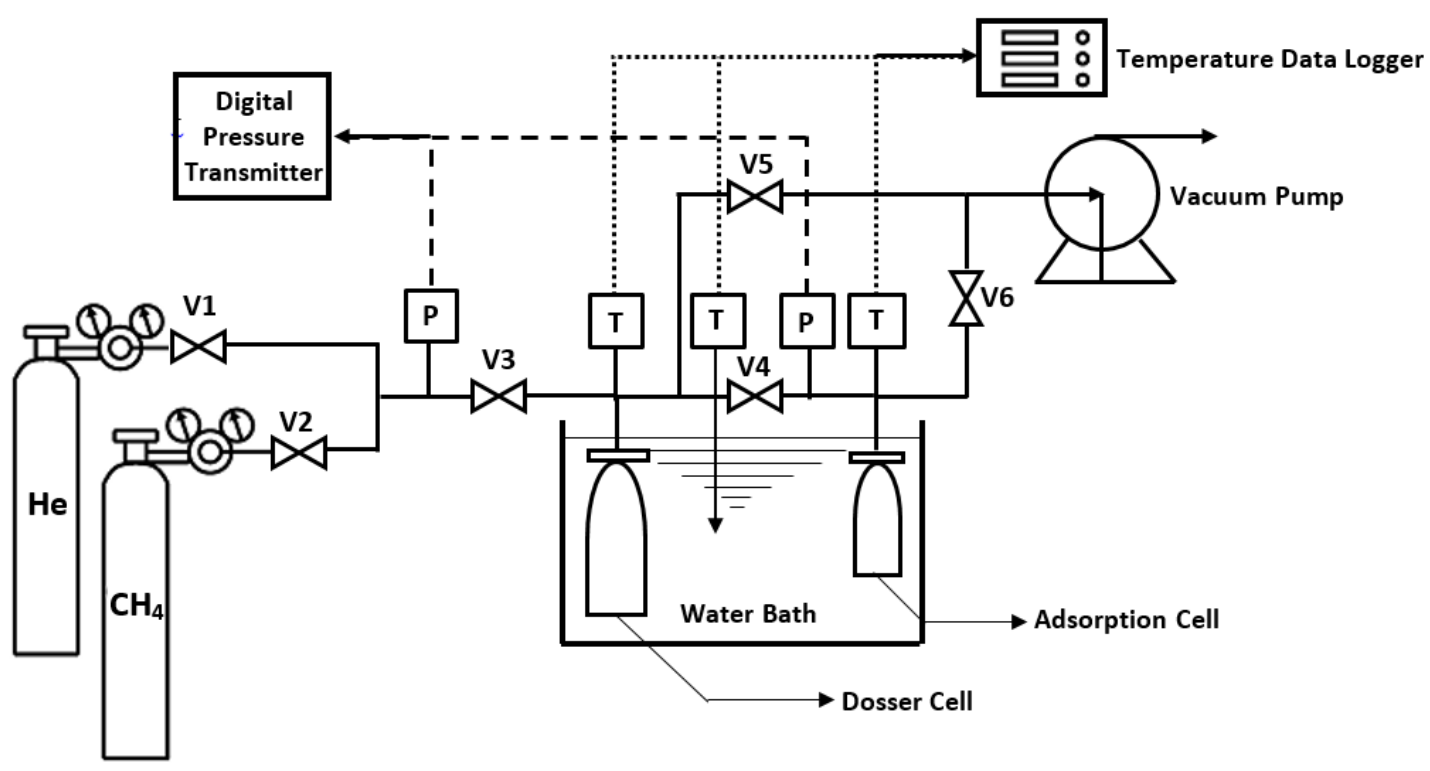

Figure 2. Schematic arrangement of the $\mathrm{CH}_{4}$ adsorption apparatus. $V, P$, and $T$ are representative of the needle valve, pressure transducer, and PT100 temperature sensors, respectively.

\subsubsection{ANG vessel}

A custom build ANG vessel has been used to evaluate the performance of the CTP-based adsorbent over multiple $\mathrm{CH}_{4}$ charge/discharge tests (Figure 3). The cyclic operation was accomplished in a 
stainless-steel cylindrical vessel equipped with a central gas diffuser, with an inside diameter of $50 \mathrm{~mm}$ and length of $135 \mathrm{~mm}$. The measured total volume of the storage chamber was $275 \pm 0.05 \mathrm{~cm}^{3}$. The wall thickness of $25 \mathrm{~mm}$ and a top hardware thickness of $30 \mathrm{~mm}$ were selected to assure the safety of the vessel during the operating condition [30]. The thermal gradient of the ANG vessel was evaluated during the cycle tests using eight PT100 temperature sensors distributed through the vessel as follow: three sensors radially placed with a spacing of $11 \mathrm{~mm}$, four sensors axially located with a spacing of $4.34 \mathrm{~mm}$ and last one sited near the inlet gas on the chamber wall (to monitor the inlet gas temperature). A portable pressure indicator rated up to 150 bar was connected to the ANG cell to control the pressure.

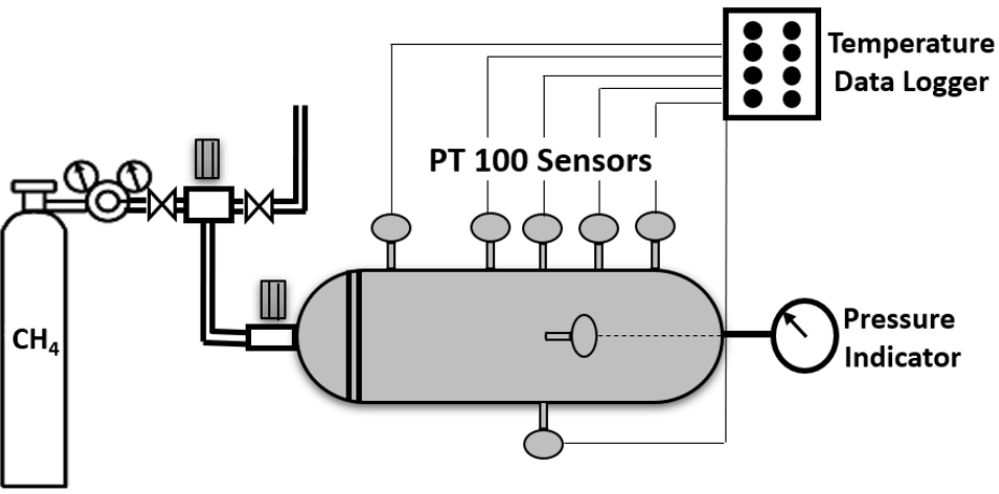

Figure 3. The experimental device of ANG vessel.

\section{Results and Discussion}

\subsection{Preparation of CTP based activated carbon}

\subsubsection{Effect of pre-treatment on the structure of CTP}

Accurate results from the ultimate analysis of CTP samples after acid treatment and carbonization steps provide valuable information about the impact of these pre-treatments on the chemical composition of CTP. The results obtained from the ultimate analysis, including fixed carbon, hydrogen, nitrogen and sulfur contents of the CTP samples are summarized in Table 1. There is a slight difference between the two samples of raw and acidized CTP. The value of carbon and hydrogen content is increased in the acid-treated sample. Also, a low rise in nitrogen contents of the acidized sample, indicating a formation of $\mathrm{N}$-functional group during the nitric acid treatment [31]. 
189 Closer inspection of the results shows there is a clear trend between increasing the carbonization

190 temperature and raise in the carbon content of the pitch-based samples. During the carbonization step,

191 non-aromatic compounds are first aromatized, afterward polymerization and development of the

192 aromatic molecules happen. All over the reactions in the carbonization process, non-carbon ingredients

193 are volatilized in the form of gases such as $\mathrm{H}_{2}, \mathrm{CO}_{2}, \mathrm{CO}, \mathrm{CH}_{4}$, and $\mathrm{H}_{2} \mathrm{O}$, which causes an increase in the

194 carbon content of the carbonized samples [6]. Hence, increasing of the carbonization temperature up to

$195700^{\circ} \mathrm{C}$ leads to enhancement in the $\mathrm{C} / \mathrm{H}$ ratio of the samples, remarkably.

Figure 4 shows the FTIR spectra of the raw, treated, and activated CTP samples. The organic peaks in two separated regions of below $1700 \mathrm{~cm}^{-1}$ and around $2300 \mathrm{~cm}^{-1}$ denote noticeable IR bands for all the samples. Quantitative analysis of organic functional groups below the wavenumber of $2000 \mathrm{~cm}^{-1}$, specifies four kinds of major organic peaks comprising $\mathrm{C}-\mathrm{O}-\mathrm{C}$ stretching at $1110 \mathrm{~cm}^{-1}$, aromatic $\mathrm{C}=\mathrm{C}$ at $1410 \mathrm{~cm}^{-1}, \mathrm{COOH}$ at $1630 \mathrm{~cm}^{-1}$ and aliphatic functional group at $1890 \mathrm{~cm}^{-1}$. Also, it is discernible that in wavelength around $3450 \mathrm{~cm}^{-1}$ major stretching peaks of minerals $-\mathrm{OH}$ is evident. For the acidized sample (spectrum (b)) the existence of a peak at the range of $1700-1760 \mathrm{~cm}^{-1}$ may indicate the formation of amide groups (-CO-NH-) during the acid treatment step [16, 32].

Table 1. Ultimate analysis of CTP-based samples.

\begin{tabular}{|l|c|c|c|c|c|}
\hline \multicolumn{1}{|c|}{ Sample } & $\begin{array}{c}\text { Carbonization } \\
\text { temperature }\left({ }^{\mathbf{O}} \mathbf{C}\right)\end{array}$ & $\begin{array}{c}\mathbf{C} \\
(\boldsymbol{\%})\end{array}$ & $\begin{array}{c}\mathbf{H} \\
\mathbf{( \% )}\end{array}$ & $\begin{array}{c}\mathbf{N} \\
(\boldsymbol{\%})\end{array}$ & $\begin{array}{c}\mathbf{S} \\
(\boldsymbol{\%})\end{array}$ \\
\hline Raw CTP & - & 93.10 & 4.20 & 1.73 & 0.97 \\
\hline Acidized CTP & - & 93.14 & 4.22 & 1.79 & 0.85 \\
\hline $400 \mathrm{CTP}$ & 400 & 93.89 & 4.00 & 1.42 & 0.69 \\
\hline $500 \mathrm{CTP}$ & 500 & 95.0 & 3.40 & 1.15 & 0.45 \\
\hline $600 \mathrm{CTP}$ & 600 & 96.51 & 2.59 & 0.77 & 0.13 \\
\hline $700 \mathrm{CTP}$ & 700 & 97.80 & 1.85 & 0.28 & - \\
\hline AC600CTP & Activated at 800 & 92.87 & 1.11 & - & - \\
\hline
\end{tabular}




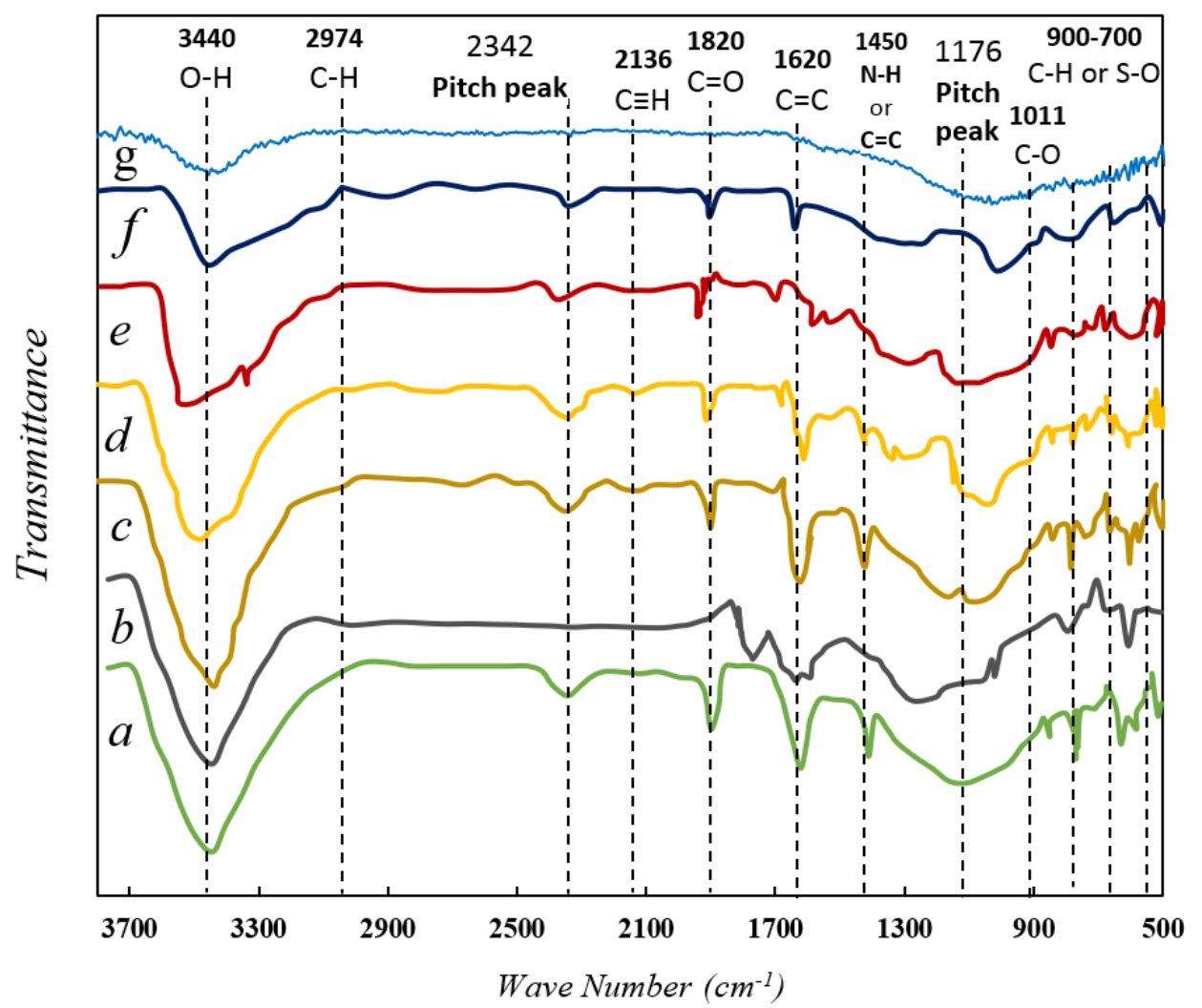

Figure 4. FTIR spectra of CTP based samples, (a) raw coal-tar pitch, (b) acidized CTP, (c) 400CTP, (d) 500CTP, (e) 600CTP, (f) 700CTP and $(g)$ activated sample of AC600CTP.

Based on the FTIR analysis of carbon samples, it is possible to investigate the impact of carbonization temperature on the chemical properties of CTP based samples (see Figure 4). The IR bands of 400CTP are quite comparable to the raw sample. However, enhancement in the carbonization temperature leads to a reduction in the intensity of the functional group's band, mainly due to the breakdown of chemical bonds in the carbon materials. For the samples prepared at higher temperatures (i.e. 600CTP and $700 \mathrm{CTP})$, some functional groups such as alkyl species $\left(=\mathrm{CH}_{2}\right), \mathrm{C}-\mathrm{C}, \mathrm{C}-\mathrm{O}-\mathrm{C}$, and $\mathrm{C}-\mathrm{O}-\mathrm{H}$ which can serve as active sites during the $\mathrm{KOH}$ activation reaction, are weaker or disappeared. The presence of these functional groups on the surface of the carbonaceous precursor is inevitably essential during chemical activation procedures with $\mathrm{KOH}$ [33]. The alkyl group reacts with $\mathrm{KOH}$ to produce $\mathrm{K}_{2} \mathrm{CO}_{3}$ and $\mathrm{K}_{2} \mathrm{O}$; these two compounds play an essential role in the chemical activation process. The reduction of these functional groups in the matrix structure of the carbonized samples has a negative effect on the formation of appropriate micropore distributions.

FTIR spectrum of AC600CTP illustrates how the chemical activation procedure affects the surface chemistry of the chars. Several characteristically broad peaks which were observed in the raw and carbonized coal samples are absent in activated CTP sample, possibly due to the breakdown of the chemical bonds in the raw and the carbonized materials [34]. Also, the intensity 

to a large extent after activation (see table 1) [35].

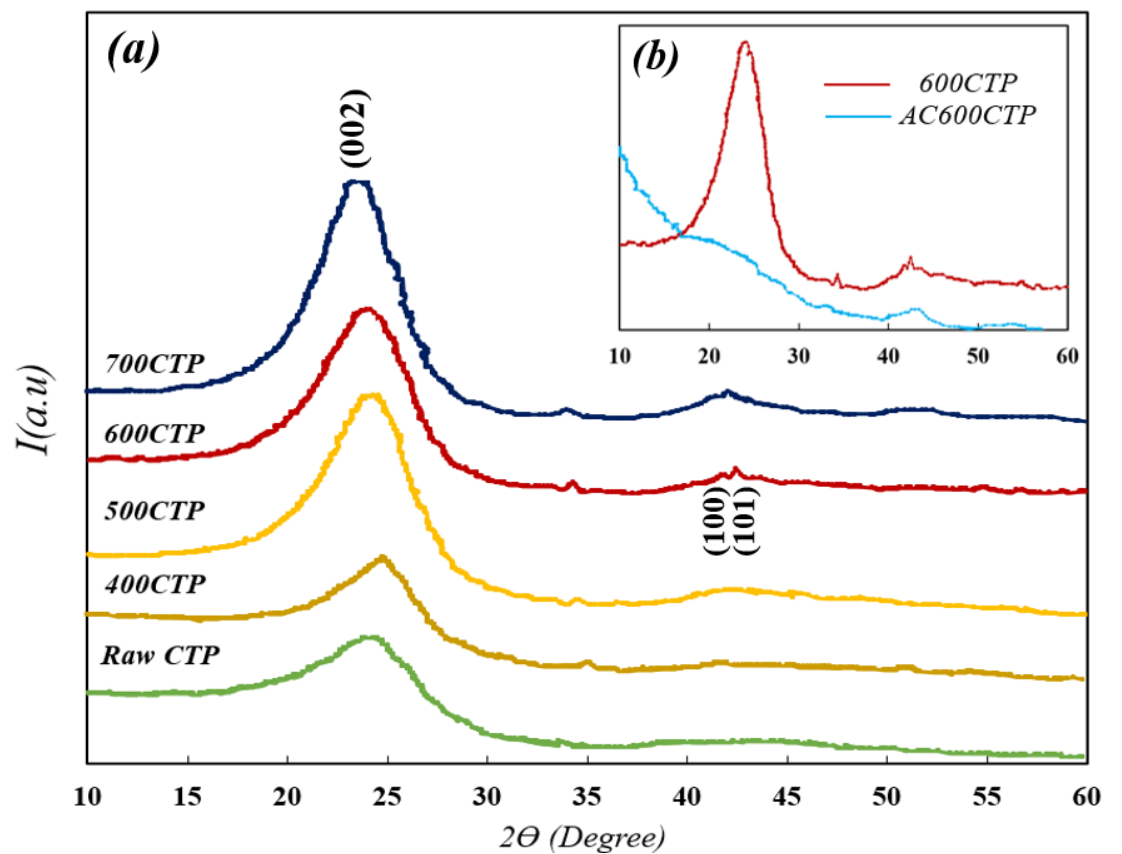

Figure 5. XRD patterns for (a) CTP based samples including raw coal-tar pitch, 400CTP, 500CTP, 600CTP, 700CTP (b) and AC600CTP.

Figures 5(a)-(b) elaborates on the effect of carbonization on the crystallinity and the matrix structure of CTP via XRD analysis. Figure 5(a) illustrates two distinguished peaks around $2 \theta=25.5^{\circ}$ and $43^{\circ}$ for each spectrum, corresponding to the diffraction of (002) and (100) planes, respectively. Based on the XRD results, increasing the carbonization temperature profoundly affects the sharpness of (002) peak and the intensity of the (100) peak. An increase in the carbonization temperature leads to improve graphitic crystallinity of the CTP precursor, which ultimately results in the sharpening of XRD peaks $[16,32]$. A decrease in irregularities in the matrix structure of the precursor as a result of increasing the carbonization temperature is another reason for the changes in the XRD patterns of the prepared ACs, proposed by Chunlan et al. [32].

240 Figure 5(b) shows the XRD pattern for the two samples of 600CTP and AC600CTP. The (002) peak 241 has vanished for the AC600CTP, which was originated from the carbonized CTP at the temperatures of $600^{\circ} \mathrm{C}$. The current result can be interpreted by the fact that the internal matrix structure of the CTP-

243 based material has been subjected to erosion during the $\mathrm{KOH}$ activation procedure, resulting in a 244 reduction of the graphitization degree of AC600CTP [7, 12, 36].

\section{$245 \quad$ 3.1.2 Development of microporosity in the activated carbon samples}

246 Nitrogen sorption isotherms were measured at $-196^{\circ} \mathrm{C}$ on the activated CTP samples and the results are

247 shown in Figure 6. According to the IUPAC classification, all the ACs show Type I isotherm which is 
implying the existence of a large portion of micropores in the structure of the adsorbents. For the

249 AC400CTP sample, adsorption isotherm has a sharp knee-shape around relative pressure of $\sim 0.03$,

250 while for three other samples, the knee is much broader. The shape of adsorption isotherms implies

251 further development of the micropores for the AC500CTP, AC600CTP and AC700CTP samples [1,

252 37]. The porous textural properties of the AC samples presented in Table 2 shows that the enhancement

253 in the carbonization temperatures higher than $500^{\circ} \mathrm{C}$, leads to a reduction in BET surface area of the

254 CTP-based ACs. The significant differences in the values of packing density and BET surface area of

255 the activated CTP samples can originate from the increase in the release of volatiles from the pitch-

256 based precursor as a result of the rise in the thermal treatment temperature (from $400{ }^{\circ} \mathrm{C}$ to $500{ }^{\circ} \mathrm{C}$ ) $[38$,

257 39].

258 Furthermore, blocked pores of the matrix structure of the carbonaceous material may be unblocked by

259 temperature enhancement [40]. Improving the porosity in the sample leads to a decrease in the packing

260 density of the adsorbents. However, when the carbonization temperature elevated up to $700{ }^{\circ} \mathrm{C}$, it is

261 expected to have decomposition and subsequent softening of some volatile fractions to form an

262 intermediate melt in the pitch materials structure. These melted materials easily block the pores, make

263 the structure of the adsorbents more compact, and decrease the microporosity $[6,25,41]$, which causes

264 an increase in the packing density of the solid [7, 40-44]. The current findings emphasize the effect of

265 the carbonization temperature on the development of microporosity in the pitch-based materials. 


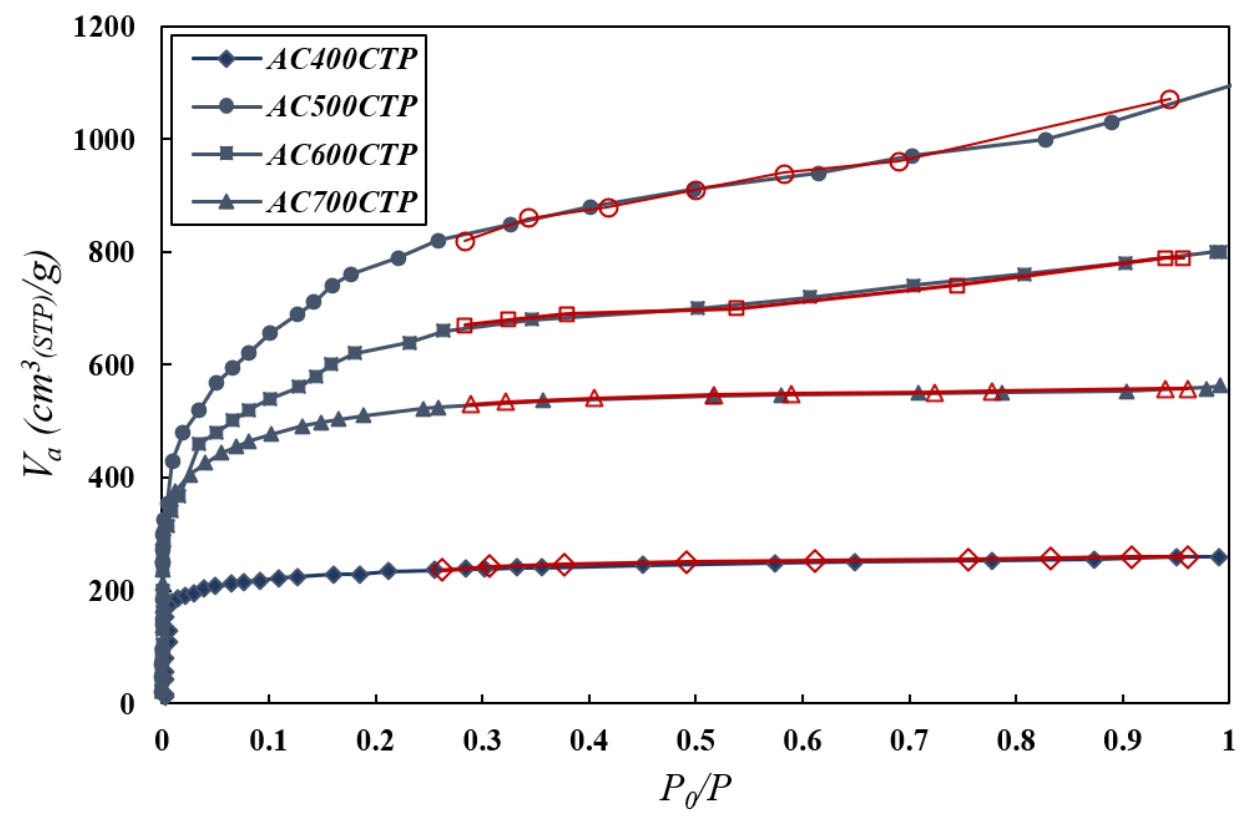

Figure 6. $\mathrm{N}_{2}$ adsorption/desorption isotherms for three activated CTP samples of AC400CTP, AC500CTP, AC600CTP and AC700CTP. Filled and empty symbols are representative for the $\mathrm{N}_{2}$ adsorption and desorption, respectively.

The effect of carbonization temperature on the pore size distribution (PSD) of activated CTPs is shown in Figure 7. For all activated samples, the dominant micropore size happens at a pore diameter range of 1-1.3 nm. The PSDs for samples of AC500CTP, AC600CTP follow a bi-modal trend, where the second peak is visible at the pore diameter region of $1.7-2.1 \mathrm{~nm}$. The second peak for the AC600CTP denotes the mesoporous characteristic of the sample. The highest amount of microporosity corresponds to the AC500CTP sample, while AC600CTP shows the development of relatively wide microporosity and narrow mesoporosity [40]. The AC400CTP adsorbent has a less amount of micropores among all ACs. These findings can be interpreted by the fact that raising the temperature at the thermal treatment step causes an enlargement of the pore size distribution in the region of the micropores, as it was shown by the analysis of the $\mathrm{N}_{2}$ adsorption isotherm. A similar observation was also reported by Liu et al. on coalderived activated carbon where they found that a higher carbonization temperature results in a larger volume of the microporosity [45]. Based on these observations, it can be concluded that the porous texture of CTP based adsorbents can be controlled by attuning the carbonization temperature $[16,46]$. 
Table 2. Porous texture characterization data for CTP samples of AC400CTP, AC500CTP, AC600CTP and AC700CTP

\begin{tabular}{|c|c|c|c|c|c|}
\hline Sample & $\begin{array}{l}\text { BET surface } \\
\text { area }\left(\mathrm{m}^{2} / g\right)\end{array}$ & $\begin{array}{c}\text { Total pore } \\
\text { volume } \\
\left(\mathrm{cm}^{3} / \mathrm{g}\right)\end{array}$ & $\begin{array}{l}\text { Micropore } \\
\text { volume } \\
\left(\mathrm{cm}^{3} / \mathrm{g}\right)\end{array}$ & $\begin{array}{l}\text { Average pore } \\
\text { diameter (nm) }\end{array}$ & $\begin{array}{c}\text { Packing density } \\
\left(\mathrm{g} / \mathrm{cm}^{3}\right)\end{array}$ \\
\hline AC400CTP & 1100 & 0.40 & 0.12 & 1.45 & $1.21 \pm 0.03$ \\
\hline AC500CTP & 2870 & 1. & 0.87 & 2.35 & $0.58 \pm 0.03$ \\
\hline AC600CTP & 2261 & 1.23 & 0.74 & 2.17 & $0.70 \pm 0.03$ \\
\hline AC700CTP & 1980 & 0.87 & 0.68 & 1.76 & $1.01 \pm 0.03$ \\
\hline
\end{tabular}

* Packing density or bulk density calculated by pressing the powder to $500 \mathrm{~kg} / \mathrm{cm}^{2}$.

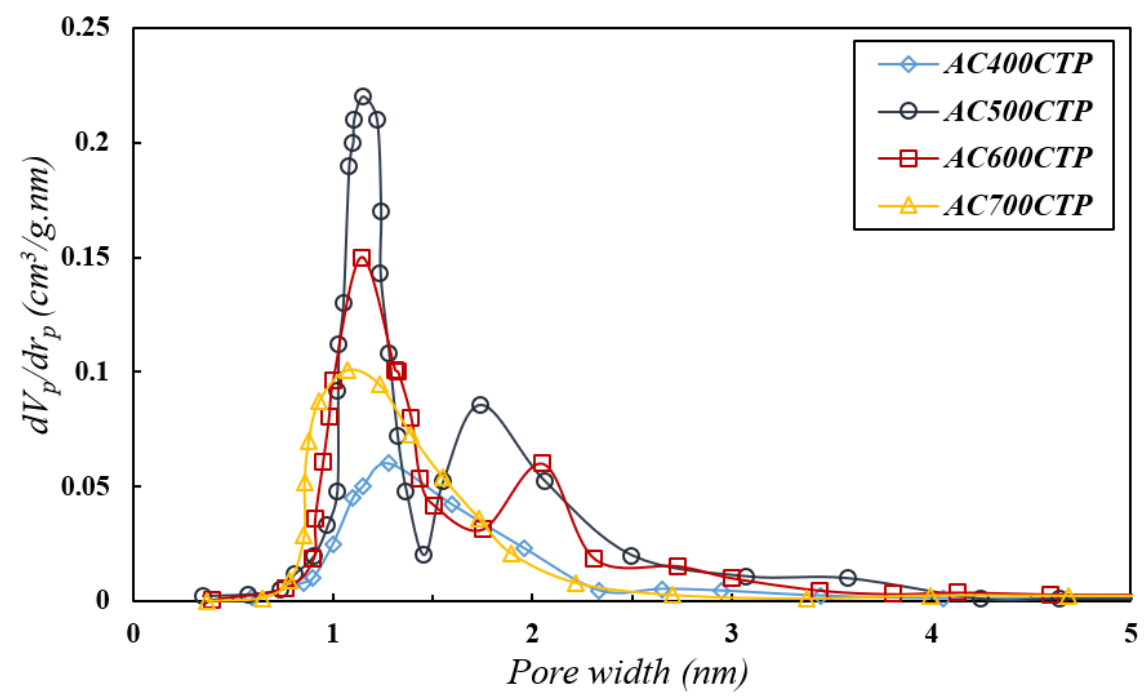

Figure 7. Pore size distribution for three activated CTP samples of AC400CTP, AC500CTP, AC600CTP and AC700CTP.

\subsection{Methane storage capacity}

Generally, $\mathrm{CH}_{4}$ uptake values can be reported in two scales of gravimetric and volumetric uptake capacity. The gravimetric uptake represents the mmol of $\mathrm{CH}_{4}$ adsorbed per unit mass of adsorbents, whereas the volumetric uptake is expressed as the volume of $\mathrm{CH}_{4}$ adsorbed under standard temperature and pressure divided by the volume of adsorbents. Our custom-built adsorption measurement setup is capable of measuring methane uptake on a gravimetric basis (mmol/g). However, for on-board vehicular applications, the volumetric storage capacity of methane $\left(\mathrm{cm}^{3}{ }_{(\mathrm{STP})} / \mathrm{cm}^{3}\right)$ is required. Many cited literature recommended using equation (1) to calculate such a conversion $[18,25,47,48]$. 


$$
\begin{aligned}
& \mathrm{Q}\left(\frac{\mathrm{cm}^{3}(\mathrm{STP})}{\mathrm{cm}^{3}}\right)=\mathrm{q} \times \rho_{\mathrm{pd}} \times \mathrm{M}_{\mathrm{w}} \times \mathrm{v}=\mathrm{q}(\mathrm{mmol} / \mathrm{g}) \times \rho_{\mathrm{pd}}\left(\mathrm{g} / \mathrm{cm}^{3}\right) \times 16(\mathrm{~g} / \mathrm{mol}) \times 1.5\left(\mathrm{dm}^{3} / \mathrm{g}\right) \\
& =\mathrm{q}(\mathrm{mmol} / \mathrm{g}) \times \rho_{\mathrm{pd}}\left(\mathrm{g} / \mathrm{cm}^{3}\right) \times 22.4\left(\mathrm{~cm}^{3} / \mathrm{mmol}\right)
\end{aligned}
$$

307 Where, $\mathrm{Q}$ is the amount of volumetric $\mathrm{CH}_{4}$ adsorption per volume of solid at standard condition $\left(\mathrm{cm}^{3}{ }_{(\mathrm{STP})} / \mathrm{cm}^{3}\right), \mathrm{q}$ is $\mathrm{CH}_{4}$ uptake $(\mathrm{mmol} / \mathrm{g}), \mathrm{M}_{\mathrm{w}}$ is the molecular weight of $\mathrm{CH}_{4}, v$ is equal to 1.5 $\mathrm{dm}^{3} / \mathrm{g}$ represents the volume occupied by $1 \mathrm{~g}$ of $\mathrm{CH}_{4}$ at the STP conditions and $\rho_{p d}$ is the packing density of the adsorbent $\left(\mathrm{g} / \mathrm{cm}^{3}\right)$.

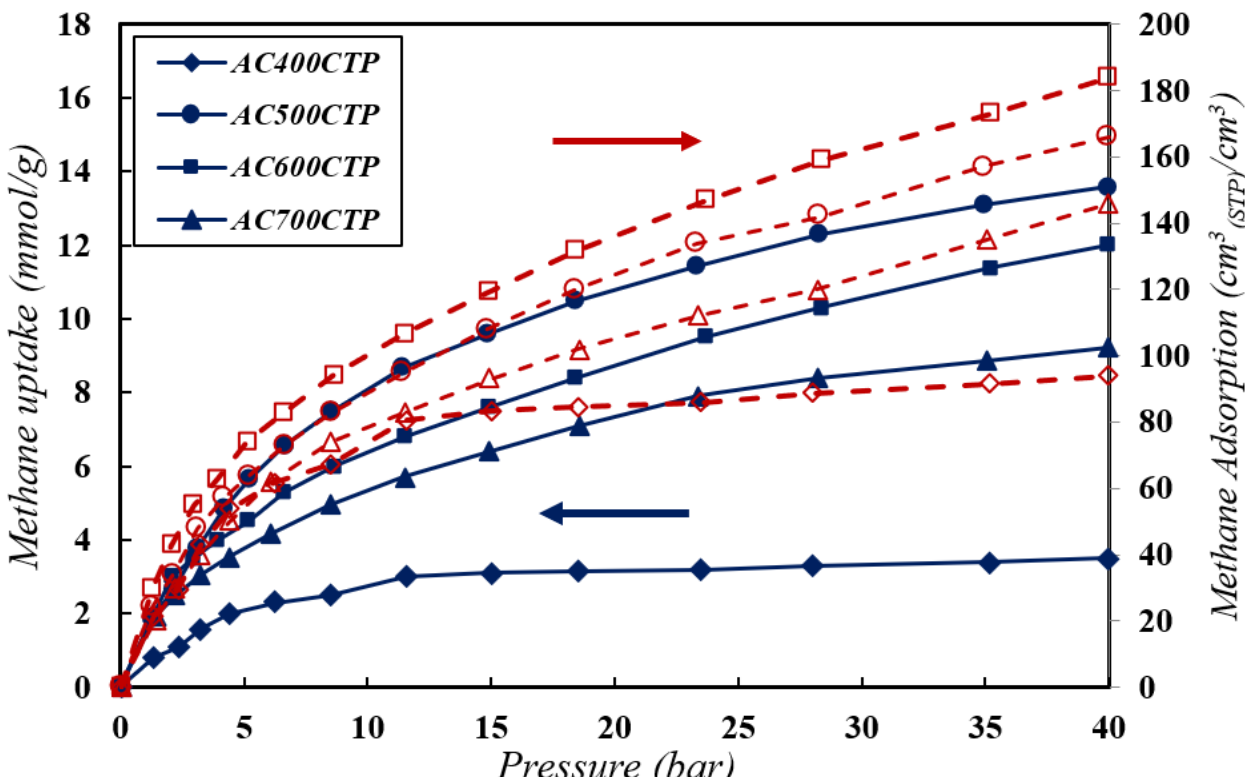

Figure 8. $\mathrm{CH}_{4}$ adsorption isotherms at $25^{\circ} \mathrm{C}$ for four activated CTP samples of AC400CTP, AC500CTP, AC600CTP, and AC700CTP. Filled-solid and empty-dotted lines are representative for the measurements in gravimetric and volumetric basis, respectively.

Figure 8 scrutinizes the $\mathrm{CH}_{4}$ adsorption isotherms on four samples of AC400CTP, AC500CTP, AC600CTP, and AC700CTP in both gravimetric and volumetric basis at $25^{\circ} \mathrm{C}$. AC700CTP with the highest carbonization temperature shows the lowest gravimetric and volumetric $\mathrm{CH}_{4}$ adsorption compared with the other ACs. Despite the superior adsorption behavior of AC500CTP in terms of gravimetric capacity $(13.6 \mathrm{mmol} / \mathrm{g})$, this adsorbent suffers from a low density compared to other samples. Since packing density has a direct impact on volumetric storage capacity, the low packing density of AC500CTP (around $0.58 \mathrm{~g} / \mathrm{cm}^{3}$ ) results in a lower volumetric capacity despite the excellent textural properties (high surface area of $2870 \mathrm{~m}^{2} / \mathrm{g}$ ). This sample with the significant development of 
porosity (micropore volume of $0.87 \mathrm{~cm}^{3} / \mathrm{g}$ ) achieves a final target of $165 \mathrm{~cm}^{3}(\mathrm{STP}) / \mathrm{cm}^{3}$ at $25^{\circ} \mathrm{C}$ and 40

327 bar, well below the value obtained by the AC600CTP $\left(184 \mathrm{~cm}^{3}{ }_{(\mathrm{STP})} / \mathrm{cm}^{3}\right)$. As it was shown in Table 2,

328 AC600CTP possesses the medium level of microporosity $\left(0.74 \mathrm{~cm}^{3} / \mathrm{g}\right)$ and packing density $\left(0.70 \mathrm{~g} / \mathrm{cm}^{3}\right)$

329 among all CTP-based adsorbents. In general speaking, the activated carbons prepared at higher

330 temperatures show a more compact structure in comparison with the others. These results stress the importance of porous texture property along with the packing density of adsorbents in ANG applications.

It is crucial to consider the volume of $\mathrm{CH}_{4}$ delivery to assess the performance of the AC samples for the ANG application [49]. The term of working capacity or the deliverable capacity describes the difference in the adsorbed amount of $\mathrm{CH}_{4}$ in the pressure range of 35 and 5 bar at the ambient temperature. As it is shown in Figure 9, the amount of $\mathrm{CH}_{4}$ working capacity for the AC600CTP is $164 \mathrm{~cm}^{3}(\mathrm{STP}) / \mathrm{cm}^{3}$.

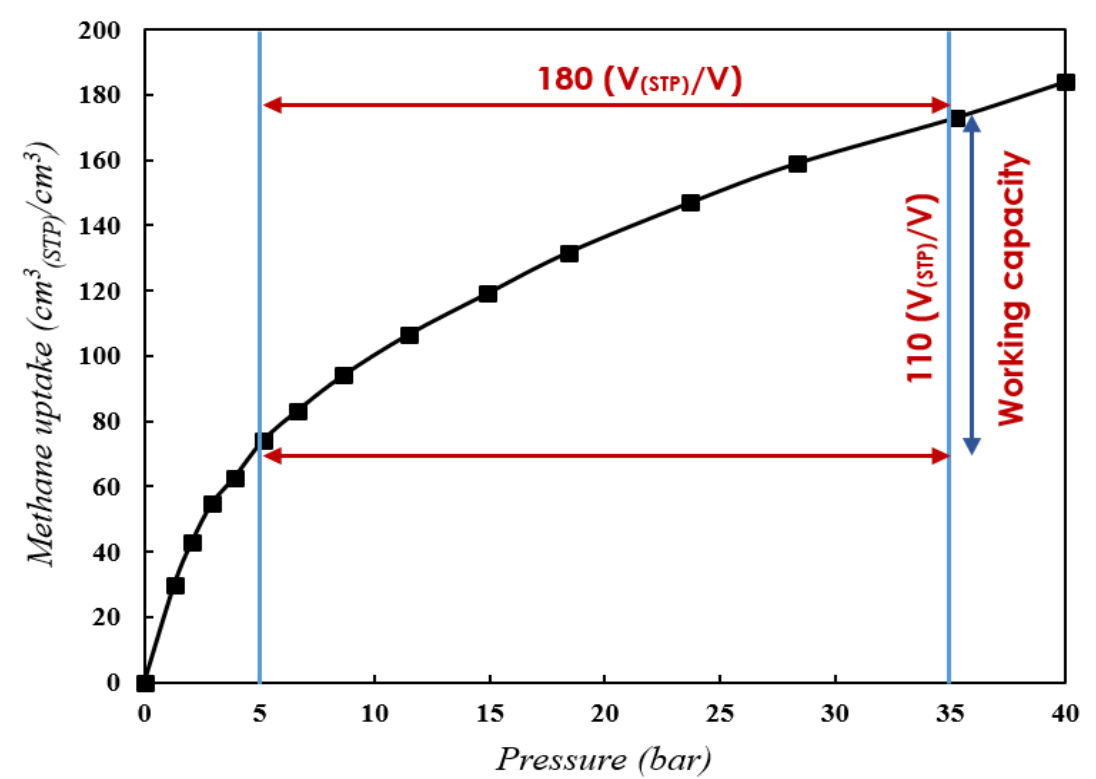

Table 3. Volumetric $\mathrm{CH}_{4}$ uptake and delivery for three samples of AC500CTP, AC600CTP and AC700CTP at 40 bar and $25^{\circ} \mathrm{C}$.

\begin{tabular}{|c|c|c|c|}
\hline Sample & $\begin{array}{c}\mathrm{CH}_{4} \text { adsorption } \\
\left(\mathrm{cm}^{\mathbf{3}}(\mathrm{STP}) / \mathbf{c m}^{\mathbf{3}}\right)\end{array}$ & $\begin{array}{l}\mathrm{CH}_{4} \text { delivery } \\
\left(\mathrm{cm}^{3}(\mathrm{STP}) / \mathrm{cm}^{3}\right)\end{array}$ & $\begin{array}{c}\mathrm{CH}_{4} \text { retained at } 5 \text { bar } \\
(\%)\end{array}$ \\
\hline AC500CTP & 170 & 95 & 39.24 \\
\hline АC600СТP & 184 & 110 & 43.49 \\
\hline АC700CTP & 146 & 80 & 37.61 \\
\hline
\end{tabular}


Table 4. $\mathrm{CH}_{4}$ adsorption and delivery data for various adsorbents at $25^{\circ} \mathrm{C}$.

\begin{tabular}{|c|c|c|c|c|c|c|}
\hline \multirow{2}{*}{$\begin{array}{c}\text { Adsorbent } \\
\text { types }\end{array}$} & \multirow{2}{*}{ Material } & \multirow{2}{*}{$\begin{array}{c}\text { BET } \\
\left(\mathbf{m}^{2} / \mathbf{g}\right)\end{array}$} & \multicolumn{2}{|c|}{$\mathrm{CH}_{4}$ adsorption } & \multirow{2}{*}{$\begin{array}{c}\text { Working capacity } \\
\mathbf{c m}^{\mathbf{3}}(\mathrm{STP}) / \mathbf{c m}^{3} \\
\end{array}$} & \multirow{2}{*}{ Ref. } \\
\hline & & & $\mathrm{mmol} / \mathrm{g}$ & $\mathbf{c m}^{3}(\mathrm{STP}) / \mathbf{c m}^{3}$ & & \\
\hline \multirow{12}{*}{ Carbon } & $\begin{array}{l}\text { Coal Tar Pitch } \\
\text { (CTP500) }\end{array}$ & 2870 & $13.6^{\mathrm{a}}$ & $170^{\mathrm{a}}$ & $95^{\mathrm{f}}$ & This work \\
\hline & $\begin{array}{l}\text { Coal Tar Pitch } \\
\text { (CTP600) }\end{array}$ & 2261 & $12^{\mathrm{a}}$ & $184^{\mathrm{a}}$ & $110^{\mathrm{f}}$ & This work \\
\hline & $\begin{array}{l}\text { Coal Tar Pitch } \\
\text { (CTP700) }\end{array}$ & 1980 & $9.4^{\mathrm{a}}$ & $146^{\mathrm{a}}$ & $80^{\mathrm{f}}$ & This work \\
\hline & Anthracites & 2864 & - & $176^{\mathrm{b}}$ & $160^{g}$ & {$[18]$} \\
\hline & Bituminous & 2123 & - & $165^{\mathrm{b}}$ & $150^{\mathrm{g}}$ & {$[12]$} \\
\hline & $\begin{array}{c}\text { Petroleum } \\
\text { residues }\end{array}$ & 2700 & - & $160^{\mathrm{a}}$ & - & [40] \\
\hline & $\begin{array}{c}\text { Petroleum } \\
\text { residues }\end{array}$ & 2465 & - & $150^{\mathrm{a}}$ & - & [40] \\
\hline & Coal Tar Pitch & 1401 & $5.43^{\mathrm{b}}$ & $155^{\mathrm{a}}$ & - & {$[5]$} \\
\hline & Pet Coke & 2111 & - & $126^{\mathrm{b}}$ & $110^{\mathrm{f}}$ & [11] \\
\hline & Corncob & 2450 & - & $121^{\mathrm{a}}$ & $97^{\mathrm{f}}$ & [50] \\
\hline & Anthracites & 2179 & - & $120^{\mathrm{a}}$ & - & [23] \\
\hline & Anthracites & 2010 & - & $118^{\mathrm{b}}$ & - & [47] \\
\hline \multirow{3}{*}{ Zeolites } & $5 \mathrm{~A}$ & - & - & $104^{\mathrm{b}}$ & - & [50] \\
\hline & $13 \mathrm{X}$ & - & - & $106^{\mathrm{b}}$ & - & {$[50]$} \\
\hline & $\mathrm{CaX}$ & - & - & $98^{\mathrm{b}}$ & - & [50] \\
\hline \multirow{10}{*}{$\mathrm{MOFs}^{\mathrm{i}}$} & NU-111 & 4930 & - & $155^{\mathrm{b}}$ & $110^{\mathrm{f}}$ & {$[50]$} \\
\hline & UTSA-20 & 1620 & - & $185^{\mathrm{b}}$ & $135^{\mathrm{f}}$ & [51] \\
\hline & MIL-100(Fe) & 2482 & $0.36^{\mathrm{c}}$ & - & - & [52] \\
\hline & $\mathrm{PCN}-14$ & 2000 & - & $184^{\mathrm{b}}$ & $130^{\mathrm{f}}$ & [50] \\
\hline & Co(bdp) & 2911 & - & $161^{\mathrm{b}}$ & $155^{\mathrm{f}}$ & [50] \\
\hline & MIL-101(Cr) & 3302 & - & $160^{\mathrm{b}}$ & $125^{\mathrm{f}}$ & {$[50]$} \\
\hline & HKUST-1 & 1137 & - & $217^{\mathrm{e}}$ & $149^{\mathrm{h}}$ & [53] \\
\hline & Al-soc-MOF-1 & 5585 & - & $190^{\mathrm{e}}$ & $104^{\mathrm{h}}$ & [50] \\
\hline & MOF210 & 6240 & - & $143^{\mathrm{e}}$ & $71^{\mathrm{h}}$ & [50] \\
\hline & MOF520 & 3160 & $0.8^{\mathrm{d}}$ & - & - & [54] \\
\hline \multirow{3}{*}{$\mathrm{COFs}^{\mathrm{j}}$} & COF-8 & 1350 & - & $107^{\mathrm{e}}$ & $84^{\mathrm{h}}$ & [55] \\
\hline & COF-102 & 3620 & - & $145^{\mathrm{e}}$ & $123^{\mathrm{h}}$ & [55] \\
\hline & COF-10 & 3530 & - & $135^{\mathrm{e}}$ & $114^{\mathrm{h}}$ & [55] \\
\hline $\mathrm{POPs}^{\mathrm{k}}$ & PPN-13 & 3420 & - & $92^{b}$ & $74^{\mathrm{f}}$ & [50] \\
\hline
\end{tabular}

345 Values of $\mathrm{CH}_{4}$ uptake measured at the pressure of ${ }^{\mathrm{a}} 40 \mathrm{bar} ;{ }^{\mathrm{b}} 35 \mathrm{bar} ;{ }^{\mathrm{c}} 1 \mathrm{bar} ;{ }^{\mathrm{d}} 1.8 \mathrm{bar}$; and ${ }^{\mathrm{e}} 65 \mathrm{bar}$.

346 Defined as the difference in the amount of $\mathrm{CH}_{4}$ adsorbed between ${ }^{\mathrm{f}} 35$ and $5 \mathrm{bar} ;{ }^{\mathrm{g}} 40$ and $1 \mathrm{bar} ;{ }^{\mathrm{h}} 65$ and 5 bar.

347 MOFs: ${ }^{\mathrm{i}}$ Metal-organic frameworks; ${ }^{\mathrm{j}} \mathrm{COFs}$ : Covalent organic frameworks, ${ }^{\mathrm{k}}$ POPs: Porous organic polymers.

348 Table 3 lists both values of the volumetric $\mathrm{CH}_{4}$ adsorption capacity at 40 bar and delivery for three

349 CTP-based adsorbents of AC500CTP, AC600CTP, and AC700CTP. The difference between total

350 storage capacity and the working capacity may be explained by the interactions between the micropore

351 surface and $\mathrm{CH}_{4}$ molecules [56]. The maximum values for $\mathrm{CH}_{4}$ delivery and retained $\mathrm{CH}_{4}$ at 5 bar

352 pressure, correspond to AC600CTP, which possess the highest $\mathrm{CH}_{4}$ adsorption capacity on a volumetric 
basis. This percentage of retained $\mathrm{CH}_{4}$ for the AC600CTP sample can be described by the existence of the relatively narrow micropore size distribution in the structure [12]. The minimum percentage of retained $\mathrm{CH}_{4}$ is related to the sample AC700CTP; it has a lower micropore volume and higher packing density in comparison with the other samples.

Table 3 shows that among all the prepared samples, AC600CTP shows the highest volumetric $\mathrm{CH}_{4}$ adsorption capacity $\left(184 \mathrm{~cm}^{3}{ }_{(\mathrm{STP})} / \mathrm{cm}^{3}\right)$. To the very best of our knowledge, this amount of stored $\mathrm{CH}_{4}$ at 40 bar pressure and ambient temperature has not been addressed previously for carbon adsorbents (see Table 4). Surprisingly, the amount of $\mathrm{CH}_{4}$ stored on AC600CTP, which is prepared from truly lowcost and abundant material, is much more significant than some kinds of the well- known adsorbent reported in the literature. The superior performance of the AC600CTP sample, which results in temperature attuning in the thermal treatment step, can significantly improve the $\mathrm{CH}_{4}$ storage capacity of tar pitch based ACs and make them suitable adsorbents for ANG applications.

\subsection{Isotherm correlations}

The temperature-dependent equilibrium adsorption model of the Toth [57], was employed to predict the $\mathrm{CH}_{4}$ storage capacity of AC600CTP. The measured data for the $\mathrm{CH}_{4}$ adsorption covers the different temperatures of 25,45 and $65^{\circ} \mathrm{C}$ and pressures up to $40 \mathrm{bar}$. These data are furnished in Table $\mathrm{S} 1$ of the supporting information (SI). The related equation of the Toth model is written as:

$$
\frac{C}{C_{0}}=\frac{K_{0} \exp \left(\frac{h_{a d s}}{R T}\right) p}{\left[1+\left(K_{0} \exp \left(\frac{h_{a d s}}{R T}\right) p\right)^{t}\right]^{1 / t}}
$$

where $C_{0}$ is the saturated amount adsorbed ( $\left.\mathrm{mmol} / \mathrm{g}\right), p$ is the equilibrium pressure (bar), $\mathrm{T}$ is absolute temperature $(\mathrm{K}), K_{0}$ is the equilibrium constant (1/bar), $h_{a d s}$ is the isosteric heat of adsorption for the empty pores of the adsorbent $(\mathrm{kJ} / \mathrm{mol}), \mathrm{R}$ is the gas constant, and $t$ is heterogeneity indicator of the adsorbent. The best-fit parameters of the model were extracted by nonlinear fitting using MATLAB software (R2018b, V9.5.0); the results are summarized in Table 5. The average regression error has also been calculated from equation (3), using the fitted model result with the experimental data. 
Average error of regression $=\frac{\sqrt{\frac{1}{N} \sum\left(C_{\text {experiment }}-C_{\text {mode }}\right)^{2}}}{\frac{1}{N} \sum C_{\text {experiment }}}$

where $\mathrm{N}$ is the number of data points. The experimental data of $\mathrm{CH}_{4}$ uptake and the predicted trends by the model are shown in Figure 10. Also, the difference between the experimental uptake and the calculated values by the model is presented in Figure S2 of the supporting information. In the case of

After evaluation the accuracy of the model, the Toth model was recruited to predict $\mathrm{CH}_{4}$ uptake at ambient temperature $\left(25^{\circ} \mathrm{C}\right)$ and 60 bar as the conditions that the U.S. Department of Energy (DOE) set the target $\mathrm{CH}_{4}$ storage capacity for ANG [58]. It was found that the predicted volumetric capacity of $\mathrm{CH}_{4}$ adsorption on the AC600CTP sample at the mentioned condition achieves a final extent of 219 $\mathrm{cm}^{3} / \mathrm{cm}^{3}$ close enough to the new DOE target (see Figure S3).

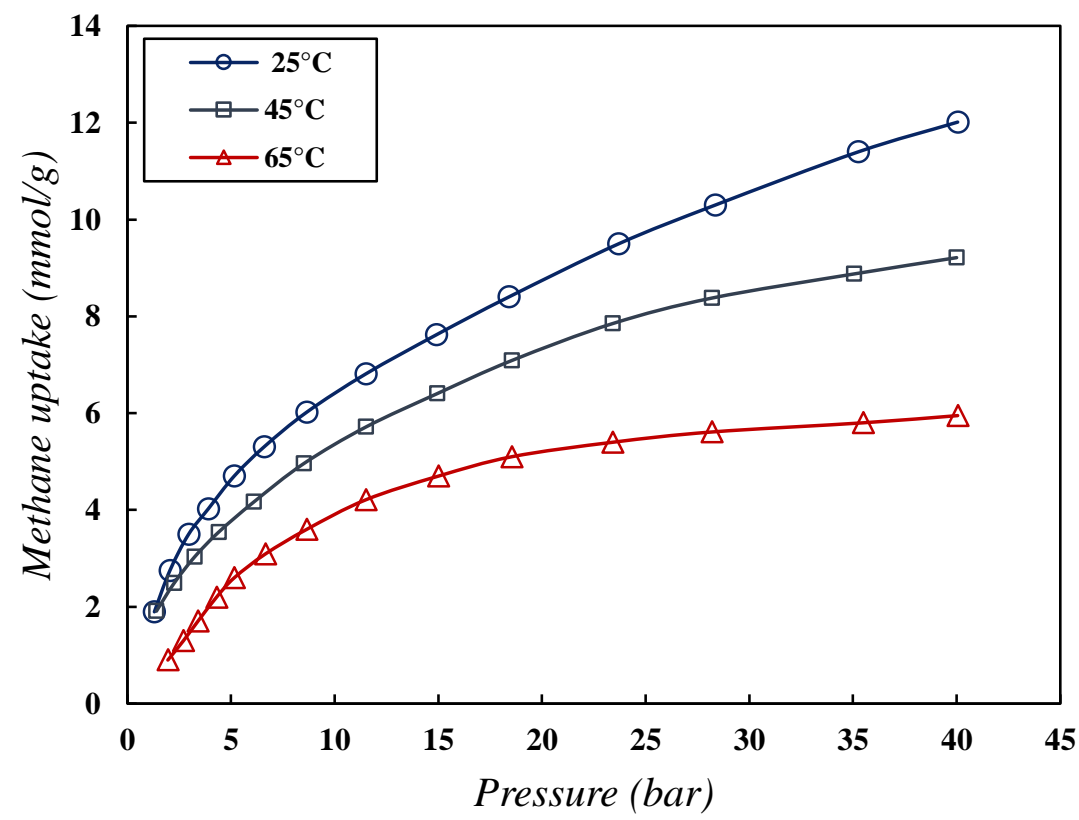

Figure 10. $\mathrm{CH}_{4}$ adsorption data of AC600CTP sample at $25^{\circ} \mathrm{C}, 45^{\circ} \mathrm{C}$ and $65^{\circ} \mathrm{C}$, solid lines symbolize the Toth model. 


\begin{tabular}{|cc|}
\hline Model parameters & Toth Model \\
\hline$C_{0}(\mathrm{mmol} / \mathrm{g})$ & $16.65 \pm 0.21$ \\
$h_{\text {ads }}(\mathrm{kJ} / \mathrm{mol})$ & $29.57 \pm 0.40$ \\
$K_{0}(1 / \mathrm{bar}) \times 10^{6}$ & $9.9 \pm 0.18$ \\
$t$ & $0.72 \pm 0.04$ \\
Regression error $(\%)$ & $3.37 \pm 0.5$ \\
\hline
\end{tabular}

393

394

395

396

397

398

402

403

404

405

406

407

408

409

410

\subsection{Isosteric heat of adsorption}

The isosteric heat of $\mathrm{CH}_{4}$ adsorption provides beneficial information about interactions between $\mathrm{CH}_{4}$ molecules and the adsorbent. This parameter plays a vital role in evaluating the thermal behavior of the ANG vessels [56]. The uptake dependence of the isosteric heat of adsorption $\left(\Delta H_{\text {isos }}\right)$ has been calculated form $\mathrm{CH}_{4}$ isotherm adsorption data using the Van't Hoff's equation:

$$
\left(\frac{\partial \ln p}{\partial 1 / T}\right)_{\theta}=-\frac{\Delta H_{\text {isos }}}{R} \quad \text { Where } \quad \theta=\frac{C}{C_{0}}
$$

Where $\Delta H_{\text {isos }}$ is the isosteric heat of adsorption $(\mathrm{kJ} / \mathrm{mol}), p$ is pressure (bar), $\mathrm{T}$ is the absolute temperature (K), $\mathrm{R}$ is the universal gas constant and $\theta$ is the surface coverage. Equation (6) which is the developed form of the above equation, represents the relationship between the equilibrium pressures $\mathrm{P}_{1}$ and $\mathrm{P}_{2}$ to the corresponding temperatures of $\mathrm{T}_{1}$ and $\mathrm{T}_{2}$ at the same surface coverage.

$$
\Delta H_{\text {isos }}=\frac{R \cdot T_{1} \cdot T_{2}}{T_{1}-T_{2}} \ln \left(p_{2} / p_{1}\right)_{\theta}
$$

Surface coverage plots at different temperatures for the AC600CTP adsorbent are presented in Figure $\mathrm{S} 4$ of the supporting information. To calculate the coverage percent, the parameter of saturated adsorbed amount $\left(\mathrm{C}_{0}\right)$ has been borrowed from the Toth model. Based on equation 6 , the calculated value of $\Delta H_{\text {isos }}$ at the zero-surface coverage for AC600CTP was $24.65 \mathrm{~kJ} / \mathrm{mol}$, which implies there is a physisorption of $\mathrm{CH}_{4}$. Blanco et al. calculated the enthalpy of $\mathrm{CH}_{4}$ adsorption on Maxsorb adsorbent, in the range of 17 to $20 \mathrm{~kJ} / \mathrm{mol}$, by using the Clausius-Clapeyron method [42]. Ahmadpour et al. reported the isosteric heat behavior of $\mathrm{CH}_{4}$ on commercial activated carbon about $30 \mathrm{~kJ} / \mathrm{mol}$ using the Toth model [59]. It can be concluded that the obtained $\Delta H_{\text {isos }}$ is in good agreement with the amounts stated in the cited literature for the $\mathrm{CH}_{4}$ adsorption on activated carbon adsorbent $[57,60]$. 


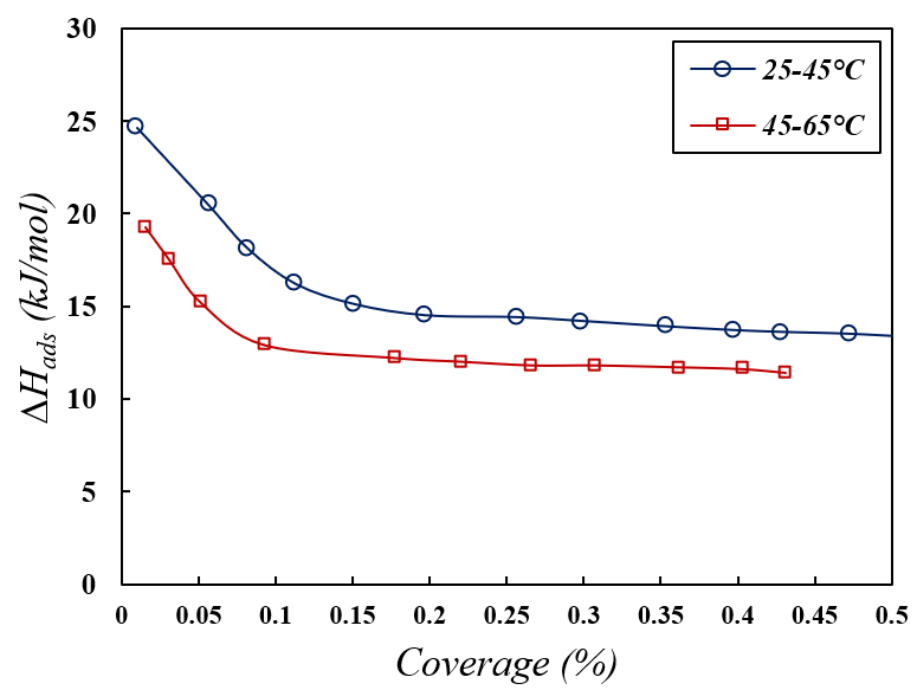

Figure 11. Isosteric heats of $\mathrm{CH}_{4}$ adsorption for AC600CTP sample verses surface coverage for two different temperature range of $\left(25-45^{\circ} \mathrm{C}\right)$ and $\left(45-65^{\circ} \mathrm{C}\right)$

Figure 11 shows the variation in the isosteric heat of adsorption versus the surface coverage for the two different ranges of temperatures on AC600CTP. These two curves illustrate a similar pattern; increasing surface coverage leads to a decrease in isosteric heat of adsorption. This reduction trend can be explained by the percentage of surface coverage. At low surface coverage (small amount of equilibrium pressure), the $\mathrm{CH}_{4}$ molecule can effectively have contact with the surface of the adsorbent, so there is a strong interaction between gas and adsorbent surface which leads to higher heat of adsorption. On the other hand, at high surface coverage, a large portion of adsorption sites has been occupied with the adsorbate. Thus, there is a little chance for $\mathrm{CH}_{4}$ to meet the surface of the pores, directly [28].

\subsection{Cyclic operation}

Two different dynamic charge/discharge experiments were conducted using the ANG vessel filled with AC600CTP at $25^{\circ} \mathrm{C}$ to analyze the performance of the prepared adsorbents for a cyclic $\mathrm{CH}_{4}$ adsorption/desorption applications. In the first experiment, ANG cell, which was under the vacuum condition, was filled with $\mathrm{CH}_{4}$ up to 40 bar, and then after reaching the equilibrium, it was discharged from 40 bar down to vacuum. This test was repeated for five cycles and the results showed that the storage capacity of the adsorbent was not affected by the number of adsorption/desorption cycles. 
In the second experiment, the ANG cell, which was under the vacuum condition, was filled with $\mathrm{CH}_{4}$ up to 40 bar, and after the system reached the equilibrium, it was discharged from 40 bar down to the atmospheric pressure ( $\sim$ bar). The rest of the cycles, up to ten cyclic tests, were carried out without evacuation in the range of (1 to 40) bar [49]. The obtained results are shown in Figure 12. During the first cycle, when the pressure drops down to 1 bar, around $10.8 \%$ of the total amount of adsorbed gas is retained in the adsorbent pores. This can explain a discrepancy between the adsorbed and delivered quantities of $\mathrm{CH}_{4}$ in the first run. The current finding shows reasonable stability for the AC600CTP over the cyclic tests. In the initial cycle, the amount of stored $\mathrm{CH}_{4}$ is high, due to the maximum retention of gas molecules in the empty pores of the adsorbent. However, after ten cycles, the efficiency of $\mathrm{CH}_{4}$ adsorption on the activated carbon sample had a $4.1 \%$ decrease. The obtained results are in the range of the reported values for carbon materials in the literature [61, 62]. Policicchio et al. verified that after 14 adsorption/desorption cycles, $\mathrm{CH}_{4}$ capacity loss of a high surface area activated carbon (originated from Acros Organics) is more than 2-3 wt\% [63]. In another study, Prosniewski et al. showed that the useable volumetric storage capacity of carbon materials in ANG tanks for large hydrocarbons had a 16\% drop after 20 cycles [64].

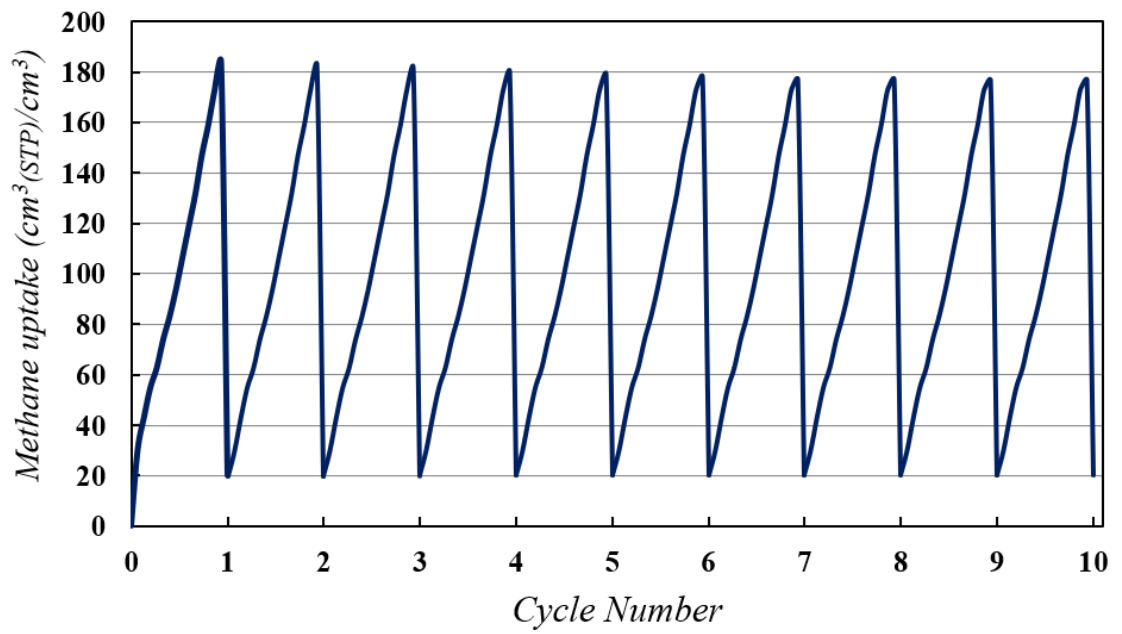

Figure 12. Cyclic operation of AC600CTP with pure $\mathrm{CH}_{4}$.

\section{Conclusions}

450 The present study was designed to enhance the $\mathrm{CH}_{4}$ adsorption capacity of the coal tar pitch (CTP)based adsorbent for ANG application. The CTP samples were modified via a two-stage treatment of acidification and carbonization before be used for activation. During the acid treatment, some of the 
volatile components of CTP effectively was eliminated at a low temperature. While, in the carbonization

454

455

456

457

process, a chain of high-temperature reactions occurred, which resulted in a pitch precursor with high carbon content. The findings of this investigation confirm that two-stage treatment can improve the structural properties of raw coal tar pitch, effectively and an optimum PSDs can be reached of the adsorbents for $\mathrm{CH}_{4}$ storage purposes by adjusting the temperature at the carbonization step. Remarkably, the activated sample of AC600CTP, with a relatively large volume of microporosity and narrow mesoporosity, exhibited a maximum amount of $\mathrm{CH}_{4}$ uptake/delivery of $184 / 164 \mathrm{~cm}^{3}(\mathrm{STP}) / \mathrm{cm}^{3}$ among all samples. Furthermore, the AC600CTP adsorbent showed very similar behavior over multiple-cycle tests. The empirical findings of this article complement those of earlier studies.

\section{Acknowledgments}

This work is supported by the Ferdowsi University of Mashhad, Iran, with scholarship support (Grant Number 44340) for Mrs. Mirzaei provided through a Postgraduate Research Scholarship.

\section{Notes}

The authors declare no competing financial interest.

\section{References:}

[1] A. Ahmadpour. Fundamental studies on preparation and characterization of carbonaceous adsorbents for natural gas storage. University of Queensland1997.

[2] V. Rozyyev, D. Thirion, R. Ullah, J. Lee, M. Jung, H. Oh, et al. High-capacity methane storage in flexible alkane-linked porous aromatic network polymers. Nat. Energy. 4 (2019) 604-11.

[3] F. Rodríguez-Reinoso, J. Silvestre-Albero. Methane Storage on Nanoporous Carbons. Nanoporous Materials for Gas Storage. Springer 2019. pp. 209-26.

[4] J.H. Cavka, C.A. Grande, G. Mondino, R. Blom. High pressure adsorption of $\mathrm{CO}_{2}$ and $\mathrm{CH}_{4}$ on Zr-MOFs. Ind. Eng. Chem. Res. 53 (2014) 15500-7.

[5] S. Gao, L. Ge, T.E. Rufford, Z. Zhu. The preparation of activated carbon discs from tar pitch and coal powder for adsorption of $\mathrm{CO}_{2}, \mathrm{CH}_{4}$ and $\mathrm{N}_{2}$. Microporous Mesoporous Mater. 238 (2017) 19-26.

[6] H. Tekinalp. Pitch-based activated carbon fibers: The effect of precursor composition on pore structure. (2011).

[7] M.J. Yoo, H.J. Ko, Y.-S. Lim, M.-S. Kim. Modification of isotropic coal-tar pitch by acid treatments for carbon fiber melt-spinning. Carbon let. 15 (2014) 247-54.

[8] K.H. Patil, S. Sahoo. Charge characteristics of adsorbed natural gas storage system based on MAXSORB III. J. Nat. Gas. Sci. Eng. 52 (2018) 267-82.

[9] T. Sesuk, P. Tammawat, P. Jivaganont, K. Somton, P. Limthongkul, W. Kobsiriphat. Activated carbon derived from coconut coir pith as high performance supercapacitor electrode material. J. Energy Storage. 25 (2019) 100910.

[10] J. Park, G. Lee, S. Hwang, J. Kim, B. Hong, H. Kim, et al. The effects of methane storage capacity using upgraded activated carbon by KOH. Appl. Sci. 8 (2018) 1596.

[11] H. Zhang, J. Chen, S. Guo. Preparation of natural gas adsorbents from high-sulfur petroleum coke. Fuel. 87 (2008) 304-11. 
[12] D. Lozano-Castello, D. Cazorla-Amoros, A. Linares-Solano. Powdered activated carbons and activated carbon fibers for methane storage: a comparative study. Energy Fuels. 16 (2002) 1321-8.

[13] Y. Sun, G. Sun. Preparation of biomass derived porous carbon: Application for methane energy storage. (2016).

[14] A. Arami-Niya, T.E. Rufford, Z. Zhu. Nitrogen-doped carbon foams synthesized from banana peel and zinc complex template for adsorption of $\mathrm{CO}_{2}, \mathrm{CH}_{4}$, and $\mathrm{N}_{2}$. Energy Fuels. 30 (2016) 7298-309.

[15] B. Tsyntsarski, B. Petrova, T. Budinova, N. Petrov, M. Krzesinska, S. Pusz, et al. Carbon foam derived from pitches modified with mineral acids by a low pressure foaming process. Carbon. 48 (2010) 3523-30.

[16] P.R. Choi, E. Lee, S.H. Kwon, J.C. Jung, M.-S. Kim. Characterization and organic electricdouble-layer-capacitor application of $\mathrm{KOH}$ activated coal-tar-pitch-based carbons: Effect of carbonization temperature. J. Phys. Chem. Solids. 87 (2015) 72-9.

[17] B. Apicella, A. Tregrossi, F. Stazione, A. Ciajolo, C. Russo. Analysis of petroleum and coal tar pitches as large PAH. Chem. 57 (2017) 775-80.

[18] A. Ahmadpour, H. Rashidi, M.J.D. Mahboub, M.R. Farmad. Comparing the performance of $\mathrm{KOH}$ with $\mathrm{NaOH}$-activated anthracites in terms of methane storage. Adsorp. Sci. Technol. 31 (2013) 729-45.

[19] A. Ahmadpour, N. Jahanshahi, S. Rashidi, N. Chenarani, M.J.D. Mahboub. Application of artificial neural networks and adaptive neuro-fuzzy inference systems to predict activated carbon properties for methane storage. Adsorp. Sci. Technol. 32 (2014) 275-90.

[20] M.J.D. Mahboub, A. Ahmadpour, H. Rashidi, N. Jahanshahi. Investigating parameters on the preparation of mesoporous activated carbons by the combination of chemical and physical activations using the Taguchi method. Adsorption. 18 (2012) 297-305.

[21] A. Okhovat, A. Ahmadpour. A comparative study of the effects of different chemical agents on the pore-size distributions of macadamia nutshell-based activated carbons using different models. Adsorp. Sci. Technol. 30 (2012) 159-69.

[22] A. Arami-Niya, W.M.A.W. Daud, F.S. Mjalli, F. Abnisa, M.S. Shafeeyan. Production of microporous palm shell based activated carbon for methane adsorption: modeling and optimization using response surface methodology. Chem. Eng. Res. Des. 90 (2012) 776-84.

[23] F. Rodríguez-Reinoso. Porous carbons in gas separation and storage. Combined and Hybrid Adsorbents. Springer 2006. pp. 133-44.

[24] A. D2854-09(2014). Standard Test Method for Apparent Density of Activated Carbon. ASTM International, West Conshohocken, PA,2014. p. www.astm.org.

[25] D. Lozano-Castello, D. Cazorla-Amoros, A. Linares-Solano, D. Quinn. Influence of pore size distribution on methane storage at relatively low pressure: preparation of activated carbon with optimum pore size. Carbon. 40 (2002) 989-1002.

[26] A. Martin, W.S. Loh, K.A. Rahman, K. Thu, B. Surayawan, M.I. Alhamid, et al. Adsorption isotherms of $\mathrm{CH}_{4}$ on activated carbon from Indonesian low grade coal. J. Chem. Eng. Data. 56 (2011) 361-7.

[27] J. Luo, Y. Liu, C. Jiang, W. Chu, W. Jie, H. Xie. Experimental and modeling study of methane adsorption on activated carbon derived from anthracite. J. Chem. Eng. Data. 56 (2011) 491926.

[28] W. Zhou, H. Wu, M.R. Hartman, T. Yildirim. Hydrogen and methane adsorption in metalorganic frameworks: a high-pressure volumetric study. J. Phys. Chem. C. 111 (2007) 16131-7.

[29] R.B. Rios, F.W.M. Silva, A.E.B. Torres, D.C. Azevedo, C.L. Cavalcante. Adsorption of methane in activated carbons obtained from coconut shells using $\mathrm{H}_{3} \mathrm{PO}_{4}$ chemical activation. Adsorption. 15 (2009) 271-7.

[30] M.S. Manai, M. Leturia, C. Pohlmann, J. Oubraham, S. Mottelet, M. Levy, et al. Comparative study of different storage bed designs of a solid-state hydrogen tank. J. Energy Storage. 26 (2019) 101024. 
[31] B. Tsyntsarski, B. Petrova, T. Budinova, N. Petrov, L.F. Velasco, J.B. Parra, et al. Porosity development during steam activation of carbon foams from chemically modified pitch. Microporous Mesoporous Mater. 154 (2012) 56-61.

[32] L. Chunlan, X. Shaoping, G. Yixiong, L. Shuqin, L. Changhou. Effect of pre-carbonization of petroleum cokes on chemical activation process with KOH. Carbon (2005) 2295-2301.

[33] Y. Yamashita, K. Ouchi. Influence of alkali on the carbonization process-II: Carbonization of various coals and asphalt with $\mathrm{NaOH}$. Carbon. 20 (1982) 47-53.

[34] O.P. Junior, A.L. Cazetta, R.C. Gomes, É.O. Barizão, I.P. Souza, A.C. Martins, et al. Synthesis of $\mathrm{ZnCl} 2$-activated carbon from macadamia nut endocarp (Macadamia integrifolia) by microwave-assisted pyrolysis: Optimization using RSM and methylene blue adsorption. $J$. Anal. Appl. Pyrol. 105 (2014) 166-76.

[35] Z.-Y. Zhong, Q. Yang, X.-M. Li, K. Luo, Y. Liu, G.-M. Zeng. Preparation of peanut hull-based activated carbon by microwave-induced phosphoric acid activation and its application in Remazol Brilliant Blue R adsorption. Ind. Crops. Prod. 37 (2012) 178-85.

[36] N. Bader, A. Ouederni. Functionalized and metal-doped biomass-derived activated carbons for energy storage application. J. Energy Storage. 13 (2017) 268-76.

[37] A. Shahsavand, M.N. Shahrak. Reliable prediction of pore size distribution for nano-sized adsorbents with minimum information requirements. Chem. Eng. J. 171 (2011) 69-80.

[38] D. Prahas, Y. Kartika, N. Indraswati, S. Ismadji. Activated carbon from jackfruit peel waste by $\mathrm{H}_{3} \mathrm{PO}_{4}$ chemical activation: pore structure and surface chemistry characterization. Chem. Eng. J.140 (2008) 32-42.

[39] A. Kumar, H.M. Jena. Preparation and characterization of high surface area activated carbon from Fox nut (Euryale ferox) shell by chemical activation with $\mathrm{H}_{3} \mathrm{PO}_{4}$. Results. Phys. 6 (2016) 651-8.

[40] M.E. Casco, M. Martinez-Escandell, K. Kaneko, J. Silvestre-Albero, F. Rodríguez-Reinoso. Very high methane uptake on activated carbons prepared from mesophase pitch: a compromise between microporosity and bulk density. Carbon. 93 (2015) 11-21.

[41] K. Gergova, N. Petrov, V. Minkova. A comparison of adsorption characteristics of various activated carbons. J. Chem. Technol. Biotechnol. 56 (1993) 77-82.

[42] A.A.G. Blanco, A.F. Vallone, S.A. Korili, A. Gil, K. Sapag. A comparative study of several microporous materials to store methane by adsorption. Microporous Mesoporous Mater. 224 (2016) 323-31.

[43] M.E. Casco, M. Martínez-Escandell, E. Gadea-Ramos, K. Kaneko, J. Silvestre-Albero, F. Rodríguez-Reinoso. High-pressure methane storage in porous materials: are carbon materials in the pole position? Chem. Mat. 27 (2015) 959-64.

[44] W.M.A.W. Daud, W.S.W. Ali, M.Z. Sulaiman. The effects of carbonization temperature on pore development in palm-shell-based activated carbon. Carbon. 38 (2000) 1925-32.

[45] L. Liu, Z. Liu, J. Yang, Z. Huang, Z. Liu. Effect of preparation conditions on the properties of a coal-derived activated carbon honeycomb monolith. Carbon. 45 (2007) 2836-42.

[46] P.R. Choi, S.-G. Kim, J.C. Jung, M.-S. Kim. High-energy-density activated carbon electrode for organic electric-double-layer-capacitor using carbonized petroleum pitch. Carbon Let. 22 (2017) 70-80.

[47] A. Perrin, A. Celzard, A. Albiniak, J. Kaczmarczyk, J. Mareche, G. Furdin. NaOH activation of anthracites: effect of temperature on pore textures and methane storage ability. Carbon. 42 (2004) 2855-66.

[48] D. Lozano-Castello, M. Lillo-Rodenas, D. Cazorla-Amorós, A. Linares-Solano. Preparation of activated carbons from Spanish anthracite: I. Activation by KOH. Carbon. 39 (2001) 741-9.

[49] M. Prosniewski, A. Gillespie, E. Knight, T. Rash, D. Stalla, J. Romanos, et al. Evaluating methane adsorbed film densities on activated carbon in dynamic systems. J. Energy Storage. 20 (2018) 357-63.

[50] B. Liu, W. Wang, N. Wang. Preparation of activated carbon with high surface area for highcapacity methane storage. J. Energy Chem. 23 (2014) 662-8. 
[51] I. Senkovska, S. Kaskel. High pressure methane adsorption in the metal-organic frameworks $\mathrm{Cu}_{3}(\mathrm{btc})_{2}, \mathrm{Zn}_{2}(\mathrm{bdc})_{2} \mathrm{dabco}$, andCr ${ }_{3} \mathrm{~F}(\mathrm{H} 2 \mathrm{O})_{2} \mathrm{O}(\mathrm{bdc})_{3}$. Microporous Mesoporous Mater. 112 (2008) 108-15.

[52] B. Yuan, X. Wang, X. Zhou, J. Xiao, Z. Li. Novel room-temperature synthesis of MIL-100 (Fe) and its excellent adsorption performances for separation of light hydrocarbons. Chem. Eng. J.. 355 (2019) 679-86.

[53] Q. Al-Naddaf, M. Al-Mansour, H. Thakkar, F. Rezaei. MOF-GO Hybrid Nanocomposite Adsorbents for Methane Storage. Ind. Eng. Chem. Res. 57 (2018) 17470-9.

[54] B. Szczęśniak, J. Choma, M. Jaroniec. Development of activated graphene-MOF composites for $\mathrm{H} 2$ and CH 4 adsorption. Adsorption. 25 (2019) 521-8.

[55] H. Furukawa, O.M. Yaghi. Storage of hydrogen, methane, and carbon dioxide in highly porous covalent organic frameworks for clean energy applications. J. Am. Chem. Soc. 131 (2009) 887583.

[56] B. Li, H.-M. Wen, W. Zhou, J.Q. Xu, B. Chen. Porous metal-organic frameworks: promising materials for methane storage. Chem. 1 (2016) 557-80.

[57] D.D. Do. Adsorption analysis: equilibria and kinetics. Imperial college press London 1998.

[58] T. Tian, Z. Zeng, D. Vulpe, M.E. Casco, G. Divitini, P.A. Midgley, et al. A sol-gel monolithic metal-organic framework with enhanced methane uptake. Nat. Mat. 17 (2018) 174.

[59] A. Ahmadpour, K. Wang, D. Do. Comparison of models on the prediction of binary equilibrium data of activated carbons. AIChE J. 44 (1998) 740-52.

[60] A. Ahmadpour, d.d. Do. Isosteric heat: a criterion for equilibrium model selection. Adsorp. Sci. Technol. pp. 36-40.

[61] M. Abdollahi, E.N. Lay, E. Sanjari. Experimental Analysis on Effects of Cycling Operation of Methane Adsorption and Desorption on Monolithic Activated Carbon. Energy Procedia. 141 (2017) 332-8.

[62] O. Pupier, V. Goetz, R. Fiscal. Effect of cycling operations on an adsorbed natural gas storage. Chem. Eng. Process. 44 (2005) 71-9.

[63] A. Policicchio, E. Maccallini, R.G. Agostino, F. Ciuchi, A. Aloise, G. Giordano. Higher methane storage at low pressure and room temperature in new easily scalable large-scale production activated carbon for static and vehicular applications. Fuel. 104 (2013) 813-21.

[64] M. Prosniewski, T. Rash, J. Romanos, A. Gillespie, D. Stalla, E. Knight, et al. Effect of cycling and thermal control on the storage and dynamics of a 40-L monolithic adsorbed natural gas tank. Fuel. 244 (2019) 447-53. 